\title{
Exporting to Russia? \\ Entry Barriers for Food Suppliers in a Territory in Transition
}

Thomsen, Lotte

\author{
Document Version \\ Accepted author manuscript
}

Published in:

Journal of Economic Geography

DOI:

10.1093/jeg/lbv016

Publication date:

2016

\section{License \\ Unspecified}

Citation for published version (APA):

Thomsen, L. (2016). Exporting to Russia? Entry Barriers for Food Suppliers in a Territory in Transition. Journal of Economic Geography, 16(4), 831-847. https://doi.org/10.1093/jeg/lbv016

Link to publication in CBS Research Portal

\section{General rights}

Copyright and moral rights for the publications made accessible in the public portal are retained by the authors and/or other copyright owners and it is a condition of accessing publications that users recognise and abide by the legal requirements associated with these rights.

Take down policy

If you believe that this document breaches copyright please contact us (research.lib@cbs.dk) providing details, and we will remove access to the work immediately and investigate your claim. 


\title{
Exporting to Russia?: Entry Barriers for Food Suppliers in a Territory in Transition
}

\section{Lotte Thomsen}

\author{
Journal article (Post print version)
}

This is a pre-copyedited, author-produced version of an article accepted for publication in Journal of Economic Geography following peer review. The version of record:

Exporting to Russia? : Entry Barriers for Food Suppliers in a Territory in Transition. / Thomsen, Lotte. In: Journa/ of Economic Geography, Vol. 16, No. 4, 07.2016, p. 831-847.

is available online at: https://doi.org/10.1093/jeg//bv016

Uploaded to Research@CBS: December २०16 


\title{
EXPORTING TO RUSSIA? ENTRY BARRIERS FOR FOOD SUPPLIERS IN A TERRITORY IN TRANSITION
}

Lotte Thomsen

Post- Print Version. Please quote as: Thomsen, Lotte (2016) Exporting to Russia? Entry barriers for food suppliers in a territory in transition. Journal of Economic Geography 16:4. Pp 831-847. Oxford University Press

Corresponding author: Lotte Thomsen, Department of Intercultural Communication and Management, Copenhagen Business School, Porcelaenshaven 18B, 2000 Frederiksberg, Denmark.Email: It.ikl@cbs.dk

\begin{abstract}
This paper draws on extensive fieldwork conducted in Central Asia to explore food exports to Russia. It takes its theoretical starting point in global value chain theory and pinpoints chain entry barriers relating to financing, transportation and standards. The paper also proposes rethinking the aspects of territoriality and institutional context, and suggests their integration into one concept, or rather a process of contextualizing territories. In doing so, the paper argues for a methodology that not only examines current events, but also captures change as particularly important in what we term the territory in transition examined here.
\end{abstract}

Keywords: Global value chain governance, territories in transition, Russian retail, central Asia JEL-codes F-14, L-22, L-66, L-92, P-31 


\section{INTRODUCTION}

Mapping, exploring and understanding the changing geographies of trade and production has been a key project of research on global value chains (GVCs) for decades (see, e.g., Gibbon et al., 2008). This paper is also theoretically based in GVC literature. It examines GVC suppliers in the Central Asian food production node in the form of food processing companies in Kazakhstan, Tajikistan and the Kyrgyz Republic that export to the buying node of GVCs for food in Russia (see Map 1). The paper uses the GVC approach to explore possibilities and challenges for these Central Asian suppliers in the Russian market, and thereby attempts to add and rethink certain aspects of the GVC discussion, as follows.

First, particular aspects of intrachain relations in the Central Asian region are pinpointed based on the extensively discussed GVC concept of governance (e.g. Gereffi et al., 2005). GVC governance was originally defined to determine how resources and profits flow between geographically dispersed nodes of a given chain (Gereffi, 1994). Gibbon et al. (2008) have related the continued relevance of the GVC governance concept to its ability to stress how practices and organizational forms establish a particular division of labour between the different actors in global industries. GVC research has thus improved our understanding of the globalization of food production and distribution, as well as of intrachain power relations (e.g., Dolan and Humphrey, 2004; Gibbon and Ponte, 2005). When seen from the perspective of firms in Central Asia, the chain governance of Russian buyers manifests as chain entry barriers, referring to the qualifications and resources suppliers need to enter a given GVC (see name of author withdrawn, 2007). The main contribution here is geographical in that discussion of GVC governance has hitherto mainly provided detail on buyers based in Western economies. We know much less about the sourcing practices of buyers and the impact of these on suppliers in emerging and transition economies, including those engaged in the Russian market in focus here.

Secondly, the paper focuses on the GVC concept of territoriality, which has received little attention compared to the other original GVC dimensions as defined by Gereffi (1994). While territoriality has been at the centre of discussion in global production network theory for more than a decade (see Dicken et al, 2001) the concept remains merely descriptive in nature within the GVC framework in that it refers to the spatial patterning of activities and distribution of production across nation states. This is striking, given that it has become increasingly clear that geography and institutional context are both essential factors in the ways that the value chain's restructuring and governance are situated in place (see, e.g., Neilson and Pritchard, 2009). Institutional context in end-markets has been shown to influence the sourcing strategies and practices - and 
thus the expectations to suppliers - of the retailers within them (Hess, 2004; Gibbon and Ponte, 2005; Wrigley et al., 2005; Dicken et al., 2001).

Thirdly, the paper discusses methodological and analytical implications of basing the empirical analysis on fieldwork conducted in the supplier node of the GVC only. Likewise, the fact that the entire value chain explored in this paper is situated within one region means that it presents a quite different geographical case to those explored in most $\mathrm{GVC}^{1}$ studies focused on relations between developing country suppliers and developed country buyers. The paper suggests that GVC research should examine territoriality and institutional context (Gereffi, 1994, 1995) as one GVC dimension rather than two. It is also suggested that the region explored here is best considered as a territory in transition, within which food processing firms in the Central Asian region experience a number of challenges due, amongst other things, to having relatively small domestic markets and being landlocked (World Bank, 2011). The Russian market has traditionally been one of the most important international markets for Central Asian businesses, but as this paper shows, it is becoming increasingly difficult for them to access and remain in this market. The Russian market itself is in the midst of a partial shift towards modern retail formats such as domestic and foreign supermarkets, hypermarkets, discounters and convenience stores, although a variety of other arrangements such as street markets and bazaars remain relatively important (Belaya and Hanf, 2010).

(Map 1 about here)

This paper is organized as follows. First, a brief outline of the literature on GVC governance and supplier entry barriers to GVCs is provided. Second, the GVC dimensions of territoriality and institutional context are discussed, and the concept of contextualized territory, and a related process of contextualizing territory, is suggested. Third, the data collection methodology is briefly outlined, while methodological implications are assessed. Fourth, the Russian retail market is described to provide an understanding of the dynamics of the market and the buyers within it, to which Central Asian businesses export. Fifth, an empirical analysis of Central Asian food processors' exports to Russia is presented. Finally, a conclusion discusses the paper's findings.

\footnotetext{
${ }^{1}$ Notable exceptions include Pavlínek and Zenka (2011) on upgrading in automotive GVCs and Smith et al. (2014) on the related concept of global production networks for clothing in Eastern Europe.
} 


\section{CHAIN GOVERNANCE AND ENTRY BARRIERS}

It is a central proposition of the GVC approach that the possibilities for suppliers are inevitably linked to the governance structures, and thus to the strategies and decisions made and practiced by lead firms, of a given chain (e.g., Gibbon and Ponte, 2005). The lead firms in food GVCs are buyers, typically retailers such as discounters, supermarkets and department stores. An ongoing transformation of global retail has been conceptualized as, for example, 'the supermarket revolution' or 'supermarketization' (see, e.g, Reardon and Hopkins, 2006; Wrigley and Lowe, 2007). A wide literature relevant to understanding these ongoing changes exists. Major trends involve, first, a focus on global retailers - mainly supermarkets based in Western countries - and their global expansion; and also on the dynamics and power relations within their supply chains (e.g., Coe and Wrigley, 2007; Tacconelli and Wrigley, 2009; Reardon et al., 2007; Dawson, 2007; Wrigley et al., 2005; Coe and Hess, 2005; Dolan and Humphrey, 2000). Reardon et al. (2007) note that the economic geography and management literature has mainly interpreted the diffusion of supermarkets as a product of the transnationalization of retail, while the role of domestic retail sectors in emerging markets is much less examined. This analysis certainly applies to the Russian market. Second, some of this literature deals with the impact of alterations in the global retail system on suppliers. The opportunities for suppliers based in developing and transitional countries to enter GVCs, and to gain from chain participation once (or rather if) they are accepted by buyers as chain participants, are seen as essential products of chain governance. Suppliers are also often seen to be experiencing increasing demands from their existing buyers, and thus overall to be facing more and more competition in the global market. Chain entry barriers are thus determined by the conditions set by buyers in end-markets. These may include, for example, requiring that suppliers offer particular services or possess specific financial capabilities. (e.g., Humphrey and Schmitz, 2002; Gibbon and Ponte, 2005). Coe and Hess (2005, p. 452) state that 'the analysis of international supply networks in retailing needs to be seen in the context of ongoing power shifts between retailers and suppliers.' They list a number of ways that power may be exercised within supply chains, including control over pricing, inventory control, operations, channels and information. These factors serve to capture value for retailers at the expense of suppliers. The empirical section below provides an indication of how such power relations materialize in GVCs governed by Russian buyers as seen from the suppliers' perspective.

Compliance with standards has been singled out as a fundamental chain entry barrier to GVCs governed by Western buyers (see, e.g., Nadvi, 2008; Kaplinsky, 2000). Buyers' determination of the terms of trade and co-operation throughout chains have come to include governance through standards over the past three decades, due to a rise of new discourses on transparency and accountability (see, e.g., Gibbon and Lazarro, 2010). This development is closely related to the restructuring of the organization and distribution of production in, for instance, large supermarkets. Standards may be seen as legitimizing specific functional 
divisions of labour along GVCs, in terms of conventions on product quality and corporate organization (Gibbon and Ponte, 2005). Compliance with international product and process standards is now necessary for entry into GVCs driven by buyers in Western countries to such a degree that noncompliance commonly results in exclusion from profitable markets (Nadvi, 2008). Standards are important in the food sector, and may on the one hand lead to the possibility for upgrading, at least for some suppliers; on the other hand, they do also imply rising expectations of supplier capabilities. International food safety standards have thus put increasing demands on the financial, human and technological resources of developing countries, either in working towards or maintaining compliance.

\section{CONTEXTUALIZING TERRITORIES}

As mentioned above, the GVC concept of territoriality dates back to 1994 when it was defined, together with governance and input-output structure, as a basic dimension of GVCs (Gereffi, 1994). Subsequently, Gereffi (1995) added the institutional framework dimension, defined as 'the rules of the game' in national and international contexts, but provided little indication of the exact meaning of this term. While territoriality merely describes spatial patterning and distribution of production as mentioned above, institutional context is thus more about the content and processes going on within these territories. It is unclear in retrospect why these two dimensions were defined as separate, leaving the concept of institutional context to be more of an add-on than a well-integrated GVC dimension. It is not so much the spatiality of the chains as such that adds to our understanding of intrachain relations, but rather the nature of the territories with all their contextually shaped and influenced functions, including regulation, infrastructure, political economy, labour relations and so on, that are essential. We therefore suggest here that the territoriality concept is much more clearly related within the GVC framework to that of contextuality, and propose its redevelopment as the concept of contextualized territories. Analytically, such a contextualized territory would be the product of the process of 'contextualizing territory' in a conceptually integrated way that also deals with institutional and other factors. It is within such contextualized territories that buyers as well as suppliers are embedded, strategies and possibilities emerge, and chain entry barriers are constructed. The contextualized territory of the buyer node of chains in focus in this paper, namely Russia, may together with the Central Asian supply node be seen as a territory in transition. Dries et al. (2004) classify Russia as a 'third-wave transition economy,' following a first wave of economies that include the Czech Republic and Poland, and a second wave including Romania, Croatia and Bulgaria. These authors categorize Central and Eastern European countries into such waves according to their different pace of movement from the pre-transition retail sector, through a period of early transition, to a period that may be called retail globalization characterized by a strong rise in inward retail FDI and an emergence of supermarkets to a much larger extent than in the intermediate stage, which saw no 
fundamental changes in formats, procurement or distribution systems. In Russia, retail globalization emerged around 2002 (Dries et al, 2004).

\section{A SUPPLIER PERSPECTIVE ON GVC RELATIONS IN A TERRITORY}

\section{IN TRANSITION}

This section briefly presents the fieldwork methodology of the study and discusses this in relation to two pertinent implications of the relation between data collection and use in this paper, namely (i) the fact that the entire value chain explored in the paper is situated in a territory in transition, and the importance of capturing empirical change in such a context; and (ii) the applied empirical focus on Central Asian suppliers in an analysis that explores their relations to other firms in GVCs.

Coe and Hess (2005) provide insights into the emerging retail market in developing and transition economies that are also useful for our understanding of the Russian market. They divide their analysis into four broad areas, namely retail competitiveness, consumption practices, regulatory frameworks and supply network dynamics. The first three, highly interrelated areas are adopted in the section below on the Russian market below, while the fourth area of supply network dynamics is important to the methodological discussion here around studying GVC relations. Supply network dynamics may, according to Coe and Hess (2005), be (i) global in scope between global retail transnational corporations and their suppliers, or (ii) local in scope between suppliers and retailers (supermarkets) located in developing and transitional countries - in the case of this paper, the retailer cohort may be foreign as well as domestically owned. We add those supply network dynamics that are (iii) regional in scope to capture intraregional chains, in this case stretching from Central Asia to Russia. The demands that Central Asian suppliers meet from their Russian buyers were from the outset of the study expected to be distinctive from those emphasized in most GVC work. Russian buyers are themselves situated in what has been conceptualized here as a territory in transition. This means that historical regional relations dating from the Soviet era are still present and important. An important methodological point here is that studying intrachain relations in regions in transition necessitates unpacking the contextualized territory and considering a wide variety of issues and causal mechanisms. Complexities to examine in territories in transition may for example include consequences of poor logistics and infrastructure, cumbersome import/export regulation, rent seeking, historical power relations, general business environment constraints, border conflict and even war. While some of these complexities may also be present in GVCs between developing-country suppliers and developed-country buyers, it is argued here 
that the analysis of GVCs situated within territories in transition is a special case in that the transitional status of buyer as well as supplier countries means that change is exceptional and ongoing in both ends of the chain. It is therefore an important task of GVC analysis conducted in transitional territories to attempt to capture ongoing changes rather than merely explaining chain dynamics at a particular moment. In this study, we attempt to do this by consistently focusing on changes during interviews with Central Asian respondents, for instance by encouraging them to reflect on whether or how challenges mentioned were the same in previous years or have altered over time. A particular analytical challenge involves distinguishing those changes that actually do derive from the transitional context from changes arising from other possible causes. It should be noted in this connection that our fieldwork was conducted in 2009. Therefore, events occurring after this time, including the current recession in the Russian economy, are not considered in the analysis below.

Data used in this paper were originally collected for a GVC background study conducted by the author for the World Bank in 2009. That background study was used as input by the Bank for a report and intervention on expansion of trade from the Central Asian region (World Bank, 2011). The empirical section of this paper is based on a specific portion only of these data. For the World Bank report, data were collected on food processing as well as on clothing for export to a variety of markets, while this present paper focuses on food exports to Russia. Moreover, the World Bank report took a meso-to-macro-level approach to trade and infrastructure expansion, while the analysis presented here takes a much more qualitative, constructivist approach to studying Central Asian businesses and their opportunities in the Russian market. Within the three countries studied, five urban centres were included in the fieldwork: Astana and Almaty in Kazakhstan, Bishkek in the Kyrgyz Republic, and Dushanbe and Khujand in Tajikistan. Firm owners and managers were interviewed in each urban centre. The sampling of firms for the overall World Bank study was based on local directories provided by city authorities and industry associations. Due to the limited interaction by smaller Central Asian firms especially with the global economy, the businesses selected were relatively large. In each city, the ten to fifteen (depending on the overall number) largest locally owned firms in food and garments respectively, as listed in directories, were contacted. It should be noted that though these firms were among the largest available, they are not necessarily large by international standards, and do also differ in size. In addition, it turned out to be extremely difficult to get reliable data on companies' sizes, number of employees and so on. In each sector, firms were also selected for the overall World Bank study to include some that were already exporting to regional or global markets, and some that focused mainly on local markets, so that their ideas on challenges related to participating and remaining in GVCs, as well as to entering them, could be revealed. In the food sector, a total of 33 respondents in the form of Central Asian firm owners and managers in domestically owned companies were interviewed in the three countries. The 33 
respondents represented the same number of food-processing companies: nine grain-processing firms in Kazakhstan; seven producers of canned, dried and juiced fruit products in Tajikistan, and four in the Kyrgyz Republic; and meat and dairy processing firms in all three countries - four in the Kyrgyz Republic, six in Kazakhstan and three in Tajikistan. Around half of these firms were presently exporting or had previously exported at least some fraction of their products to the Russian market, while most others had made unsuccessful attempts to do so. Consequently, not all firms interviewed are directly relevant for this present paper, since they do not all export or attempt to export to Russia. The empirical analysis is thus based on interviews with those Central Asian food processers that do sell some of their products to Russia at the present or in the near past, together with those who attempted to export to Russia without luck, to capture their perceptions of the barriers they met. Finally, it should be noted that making clear analytical distinctions among suppliers from the three Central Asian countries (let alone among the five cities) and among different food products is beyond the scope of this paper, not least due to the relatively small number of firms interviewed in each area. However, the analysis does provide examples related to specific products and countries when possible.

Interviews were open ended and checklist based. They were conducted by local consultants in the three Central Asian countries, and managed and monitored by the author. A number of overall topics, inspired by insights from GVC research in various sectors, were covered during each interview. Any new and relevant information revealed during an interview was followed up, and the respondents were encouraged to define important challenges themselves. Interview questions were generally composed in such a way as to uncover challenges and possibilities for local firms, in terms of entering and remaining in GVCs. However, since challenges and possibilities for local firms differ between sectors and relate to various types of localized challenges, international and national trade regulations and sector-specific factors, interview guidelines were also modified in order to be relevant to each of the sectors or urban centres in question. The interviews thus centered on determining the challenges and possibilities facing suppliers in their attempts to enter different GVCs and markets. Another focal point was whether, and how, the terms of co-operation with their buyers had changed over time. Interview themes that questions for Central Asian respondents were composed around are shown in Box 1.

(Box 1 about here)

The empirical data collected through the firm interviews were triangulated with other types of data, including interviews with representatives of local business organizations, standardization bodies and chambers of commerce. These informants were also able to provide general knowledge on food processing and export challenges in Central Asia. 
The Central Asian suppliers are central to this study, and the empirical analysis takes its starting point in interview data collected in Central Asia. It is thus to a large extent based on the ideas of Central Asian firm owners and managers, and explores the challenges they meet in relation to other firms, that is as suppliers to buyers in Russia. As a result, the study does not conduct chain chasing - not least because managers were often unaware of the exact identities of their end-buyers. Rather, the paper uses the GVC perspective as a tool to understand and systematize the challenges relating to exporting to the Russian retail market from the perspective of Central Asian suppliers. The focus is not on the chain as such, but on the possibilities for Central Asian firms in relation to other actors in the chain. While this approach provided data on perceptions and ideas relating to being a supplier to the Russian market, as well as to how this has changed over time, it does present a rather one-sided perspective, since Russian buyers did not provide their side of the story. Such an approach has obvious limitations, especially in terms of pinpointing the relationship between changes in terms of rising entry barriers to GVCs to Russia as perceived by Central Asian suppliers, and actual changes in the strategies of Russian buyers. A relatively large number of respondents in all three Central Asian countries did point to similar challenges and changes in exporting to the Russian market during interviews, and analyses of these statements thus constitute the main empirical results of this paper. The extent to which such rising chain entry barriers are caused by changes in the sourcing strategies of Russian buyers calls for research to be done on the Russian end of the chain. Thus, only indirect indications of sourcing strategies of Russian food retailers will be drawn from the empirical analysis below.

\section{THE RUSSIAN FOOD RETAIL SECTOR IN TRANSITION}

This section deals at a general level with the Russian retail market for food. It follows Coe and Hess' (2005) analytical areas of retail competitiveness, consumption practices and regulatory frameworks, as described above. These areas assist our contextualization of the Russian territory in terms of historical and contemporary changes and serve as background for the subsequent empirical analysis of Central Asian firms that export to Russia.

Retail competitiveness mainly explains the current shift in retail structure towards supermarkets and away from local independent stores and fresh markets, due to the introduction of new store formats, pricing, marketing and so on. In Russia's case, rising retail competitiveness is strongly related to a decrease in the heavy state control over food and agribusiness systems that existed during the planned-economy era. At that time, retail only took place in the form of bazaars, street markets and state-owned stores, all of which are still relatively important in Russia, though their market share has decreased (Lorentz et al, 2006). In 2006, self- 
service formats were estimated to account for $25 \%$ of market share and rising (PricewaterhouseCoopers, 2008). There has also been a recent inflow of foreign retailers with the liberalization of the investment regime (Swinnen and Maertens, 2007). Such retail FDI may be seen as challenging the emerging domestically owned retail industry in the form of (for instance) supermarkets, not only as additional competition but also product range and prices. Nevertheless, in contrast to Central Europe, foreign retailers have not been viewed as the main avenue for Russian private sector development (Kalotay, 2008). Russia retains a relatively large share of domestic ownership of the retail sector compared to the earlier-wave countries, while foreign retailers entering Russia have not found it easy to gain market share (Kolchevnikova, 2011; Roberts, 2005). This is comparable to Tacconelli and Wrigley's (2009) finding that domestically owned retailers in China also continue to play an important role due to a number of advantages, including an intuitive understanding of local consumers and political relations. Both issues are important in Russia as well.

Consumption practices have to some extent changed with the arrival of new retail formats and FDI in Russia. Lorentz et al (2006) suggests room was created for the rise of modern retail when an emerging middle class started to favour quality and service. Consumer preferences were essentially not taken into account at all by the Russian state distribution system prior to economic reform (Kolchevnikova, 2011; Lorentz et al, 2006).

Regulatory frameworks: As in other developing and transitional economies, existing retail stores in Russia are mostly geographically concentrated in larger urban centres, especially in Moscow and St Petersburg (see, e.g., Lorentz et al., 2006). This also relates to active local regulation and promotion of new retail formats at the expense of traditional bazaars in these cities (PricewaterhouseCoopers, 2008). An essential part of retail regulation relates to market concentration, which is often seen to increase competition for GVC suppliers in Western markets. The ten largest retailers in Russia had a total market share of $13 \%$ in 2009, a figure that has been projected to keep increasing (Kolchevnikova, 2010), so it is clear that at least some degree of retail concentration is emerging. Belaya and Hanf (2010) confirm a consolidation of assets through the acquisition of smaller players by larger ones. Against this background, a step towards antimonopoly regulation was taken in 2010, when the Russian Federal law on Trade was implemented. This law sets a ceiling of 25\% market share for single retailers in any region or city, with the goal of protecting smaller retailers (Kolchevnikova, 2011). The outcome of this move remains to be seen. 


\section{EXPORTING TO RUSSIA: A CENTRAL ASIAN SUPPLIER}

\section{PERSPECTIVE}

Following the above outline of general conditions in the Russian food retail market, this empirical section adopts a Central Asian supplier perspective in order to pinpoint entry barriers met when exporting to Russia. At the overall level, these entry barriers are divided into (i) a market entry barrier, namely transportation, by which we mean a barrier for general accessibility of the Russian market rather than one related to the qualifications of single suppliers as in the case of chain entry barriers (see name of author withdrawn, 2007); and two chain entry barriers, (ii) financing and (iii) standards compliance.

On an overall note, Central Asian suppliers frequently stated during interviews that finding or keeping buyers for their products in Russia was difficult. Those that had been exporting to Russia for some time commonly stressed that they felt the level of difficulty was rising. For instance, one processor of canned fruit in the Kyrgyz Republic with around 50 employees explained:

'... my firm sold most of our product to Russia until two years ago, but we did not get any orders from them for some time, so I try to sell here and in Kazakhstan instead. I heard from somebody else that he also cannot sell to Russia right now, but maybe it will be better again later... He thinks the Russians want to buy from larger firms, but we do not know for sure. Maybe it will change again in the future' (interview, 2009).

One possible explanation for this shift is that Russian buyers' supply chain dynamics are currently influenced by changing regulation in Russia. Alteration of federal trade law in Russia has gradually led Russian retailers to change their assortment strategy and also to decrease the number of suppliers they work with (Kolchevnikova, 2011). Belaya and Hanf (2010) stress that Russian retailers currently try to concentrate their sourcing of food products with larger Russian suppliers, but point out that this change is emerging only partially. Retailers are often forced in practice to work with many smaller suppliers, due to a lack of large wholesalers. When large Russian suppliers are involved, they are, according to Belaya and Hanf (2010), mainly large Russian agricultural enterprises selected for their ability to comply with specific quality standards. What we do not really know, however, is the extent to which this involves a change in the sourcing geographies of Russian retailers to focus on Russian suppliers only; this remains to be seen. Still, the tendency does at least partially explain why Central Asian food suppliers involved in this study 
experience decreasing sales to Russia. They also often perceive this tendency as being due to rising competition from Russian suppliers.

\section{TRANSPORTATION}

Central Asian respondents very often pointed to transport and infrastructure difficulties with exporting to the Russian market. Not least, this was seen as a fundamental problem for staying competitive with local Russian food suppliers, since long transportation time and high costs are inevitably negative factors. One Kazakh flour producer, for example, who exports $90 \%$ of his products to Russia and Ukraine, explains how he sees Russian flour producers as competitors due to a combination of price and location factors:

'[Firms in] Barnaul ${ }^{2}$... are our competitors from Russia. They sell their flour to the south of their country, look where they are located! They can easily supply their flour to the rail station. They can afford to cover their transportation expenses due to their cheap ruble and could sell at $\$ 350$ per ton of flour' (interview, 2009).

Trade from Central Asia to Russia is also more generally challenged by high transport costs and long and unpredictable transit times. Such costs are linked to a combination of the remote and landlocked situation of the countries, deficiencies in the transport networks, expensive and low-quality transport and logistics services, customs valuation problems, inefficiencies at border crossing points, uncertainty created by transit through neighbouring countries and costs of informal payments and convoying (see World Bank, 2011). For example, it has been estimated that almost $50 \%$ of the transport costs for fresh and dried fruits from Tajikistan to Moscow are for bribes along the transport route (World Bank, 2005b). According to the World Bank (2005a), there is also a problem of improper transit packaging and the overloading of wagons and containers in an attempt to reduce unit transport costs. That report states that the patterns of export have altered in recent years. First, the share of processed fruit and vegetable export value increased from 56 to $78 \%$ of total horticultural exports, while their export profitability, along with that of other low-value goods, has decreased. The World Bank (2005a) has also shown that the total export value of dried fruits from Tajikistan dropped at the beginning of the new millennium, while the value of processed fruit juices increased. This reflects that the dried fruit producers in our sample are now mainly targeting their own domestic markets. Respondents also commonly mentioned a lack of storage capacity, and high rental costs

${ }^{2}$ The Russian town and industrial centre of Barnaul is located just north of Kazakhstan at the junction of the Novosibirsk-Almaty and Biysk railway lines. 
for it, as an obstacle to large-scale exports of fruit products to Russian buyers who were increasingly reluctant to finance inventories themselves. Moreover, a lack of refrigeration during transport was often mentioned as an obstacle to supplying products of the quality and standard required. This is in line with the World Bank (2005b), which reports an acute shortage of packing sheds, resulting in growers packing at field temperature and then putting items directly into unrefrigerated trucks. Consequently, when the truck enters Moscow six days later, the produce is of poor quality.

\section{FINANCING STOCK AND ORDERS}

For many Central Asian suppliers who sell their products to Russia, a major change often identified during interviews is that they are now expected to finance tasks and take on risks to a higher extent than hitherto. This applies broadly across the three countries, but was found to relate specifically to a couple of suppliers who sell directly to large Russian-owned supermarkets, and to a lesser extent to those who sell to wholesalers apparently acting as middlemen for such supermarkets. Those who described themselves as selling mainly to small-scale retailers, or to wholesalers reselling to bazaars and wet-markets, did not emphasize such challenges. These tendencies could not be confirmed for all respondents, since they did not all know (or reveal) their end-buyers. Those respondents who did state that they exported to supermarkets sometimes stressed that these as well as other Russian buyers had been important customers for years, but that the terms of contracts were in the process of changing, with more and more financial responsibility (and risk) being placed on suppliers. It was also emphasized by these respondents that Russian buyers are less willing to pay the suppliers up front than they were ten years ago. One example comes from the grain-toflour sector in Kazakhstan. This sector is long-established in the Astana region and includes private firms as well as large agro-holdings. According to Wandel (2008), most of the big players have their origin in grain trading and are sometimes part of larger, diversified conglomerates that embrace activities such as raw supply production, food processing, wholesale, retail, machinery, research and financial services. Many Kazakh exporters of flour stated during interviews that their buyers from Russia had recently become more reluctant to issue letters of credit when placing orders. They also pointed out that although this tendency had been evolving steadily over the past decade, it had become even more pronounced with the outbreak of the global financial crisis and now applied to an increasing number of Russian buyers. Thus, being able to finance orders on their own account was increasingly essential for suppliers and determined whether they were able to maintain contracts. A couple of Kazakh flour suppliers stressed that they had recently experienced nonpayment by their Russian buyers even after delivery. This has led them to try setting the terms of co-operation themselves, as explained by one manager whose buyer is a Russian wholesaler: 
'I have worked with the same Russian man for many years, and he always paid me up front, which is important to me. Suddenly he stopped doing that, and I told him I do not want to work in this way. Therefore, I started to demand payment in advance or (I will) not produce (for him) at all' (interview, 2009).

This view reveals a lack of understanding of how a market economy works, and also of the real power relationships that exist within the chain. A decrease in financial support from Russian buyers to suppliers was consistently identified across subsectors and countries as a new problem, especially by those Central Asian firms that had been selling to Russia for many years. The situation is clearly extremely problematic for suppliers in a transitional context that also influences the financial system and business environment, in which few of the firm owners had ever borrowed formal capital. It was generally pointed out by the respondents that while it may be possible to obtain loans from local banks, these are on a short-term basis, with high interest rates and subject to bureaucracy and corruption. As a consequence, any capital that can be obtained is primarily used as working capital to buy raw materials, and investment in new equipment was considered out of reach by most respondents.

Another related example of a change in the Russian market stressed by respondents concerns the service expectations of Russian retailers. The meat processing industry, which was traditionally a relatively strong component of Central Asian economies, exemplifies this. This industry had, however, been challenged by a lack of livestock due to low productivity in stock breeding at the time of fieldwork. The Kyrgyz republic is the only one of the three countries that is currently a net exporter of livestock products in Central Asia. Most trade in livestock products within the region is unregistered (World Bank, 2007). Single suppliers from all three countries - most likely falling into this unregistered export category - were, however, still exporting products such as meat, skins, hides and wool to Russia, and stated that their profits had decreased by 20 to $30 \%$ over the period 2006-2009. According to respondents, Russian buyers in these cases were smaller retailers in local market stalls and locally owned supermarkets or convenience stores. Meat processors commonly stressed that, compared to ten years ago, they were now more often asked by Russian retailers to hold stock warehouses owned by themselves or rented on their own account, and they saw this as a primary challenge. In addition to such rising costs connected to stockholding, many respondents pointed to a discrepancy between the volume of meat ordered by Russian buyers and the actual sales volume (the volume actually paid for), with the result that they often lost expected profits and experienced increased product waste. These examples point to a tendency for Russian buyers to transfer the risk associated with holding inventories upstream to suppliers, either as part of a rationalization strategy or simply because they were no longer unable to finance this themselves. Either way, respondents perceived this as signaling new terms in 
their relationships with Russian buyers. Many expressed the view that they should be compensated for such losses. The buyers also no longer guaranteed that they would buy the entire volume of products initially ordered from suppliers; instead they would only pay for what they eventually asked to be delivered. This unwillingness and/or inability of Russian buyers to pay for surplus stock was seen by the Central Asian meat producers as one of their most serious challenges at present. In most cases, surplus meat and meat products deriving from these uncollected orders are stored by the processors and sales are reattempted through other market channels - often without much success and at lower prices. The smallest meat suppliers in our sample stated that they were willing to work for less or no profit for a while, in the hope of maintaining these regular customers.

\section{STANDARDS COMPLIANCE}

Standards for food safety and hygiene were clearly a new phenomenon for Central Asian respondents in general. Some, but definitely not all, were aware that these were of increasing importance for sales to the Russian market. Certain standards that historically date back to the Soviet era were used, but were gradually being replaced in the region at the time of the fieldwork. This most likely means that Russian supermarkets in particular may be imposing stricter requirements on their suppliers today than they did when the fieldwork was conducted. This is in stark contrast to the fact that for Central Asian businesses themselves, food safety was low on the agenda, besides being challenged by transportation issues as explained above. Some differences among the three Central Asian countries were captured during the fieldwork in this respect: food safety systems were clearly best established, although not unproblematic, in Kazakhstan; while Tajikistan seemed to be the least engaged with this agenda. Tajikistan's fresh fruit and vegetable sector historically exported to Russia on a much larger scale than it does today. Tajik fruit processors in the sample, who were still exporting a part of their products to Russia or had done so previously, all stated that they faced severe competition in the Russian market due to a combination of factors such as transport costs, product quality and price, and the general difficulty of compliance with expected standards for which the necessary institutional setup was not in place in Tajikistan. A major point of concern, therefore, is whether Central Asian food processors are able to comply with the relatively new standards required by their Russian buyers and included in their supply chains. When asked about how food safety is secured upstream, processing-firm owners and managers in the Kyrgyz Republic and Tajikistan commonly stressed that they asked their suppliers (farmers) for certificates, for example from a veterinary service authorizing meat sales; and they considered this to be a guarantee of food safety. Various indicators, however, raise doubts about this, including the fact that there were usually no, or only limited, integrated systems for cooling/freezing and transportation from farms to meat processors. It should be noted that challenges relating to food safety and transport for meat and milk processors are somewhat fewer in Kazakhstan than in the other two countries 
examined here. Almaty's milk processors, for example, have their own refrigerated milk trucks, solving some of the more significant transportation challenges. According to Wandel (2008), veterinary legislation in Kazakhstan has been revised and harmonized with the requirements and principles of the WTO on veterinary and phytosanitary measures within the past decade. Moreover, since 2006, the Kazakh government has subsidized the costs of certification to international quality and safety standards (Wandel, 2008). Still, awareness of food safety and standards seemed surprisingly low among Kazakh firm managers interviewed for this study, even in the relatively mature urban centre of Almaty. They often seemed to rely on outmoded national standards just as food processors in Tajikistan and the Kyrgyz Republic do.

\section{DISCUSSION AND CONCLUSIONS}

This paper has argued that the GVC dimensions of territoriality and institutional context should be merged as one concept of contextualized territories, and a related methodological process of contextualizing territory. This is essential not least (but also not only) in regions in transition where understanding the context, rather than merely spatial patterning of production and trade, is key. It is not the territories as such, but the processes, institutions and changes emerging within them, that explain strategies, possibilities and relationships within GVCs.

Emperically, the paper has examined Central Asian suppliers' opportunities in the Russian food market. It has shown how food producers see their possibilities in this market, as well as the expectations they meet from Russian buyers, as altering in a negative direction. This broadly relates not least to financing of tasks for which Central Asian suppliers consistently point out that buyers tend to transfer risk upstream. While Central Asian suppliers thus commonly stress that entry barriers to the Russian market are currently rising, a variety of reasons may be identified for this. One reason relates to federal trade regulation within Russia that gradually leads larger Russian retailers to decrease the number of suppliers they work with (see also Belaya and Hanf, 2010). Whether this strategy is leading them to concentrate their intake geographically to Russian suppliers at the expense of Central Asian ones remains to be seen. Still, a number of factors mean that Central Asian suppliers are already less competitive in the Russian market than their Russian counterparts. These include transportation difficulties between Central Asia and Russia, not only longer lead times but also the difficulty of assuring product quality, for instance due to lack of refrigeration for 
cargo. Likewise, the delayed uptake of food safety standards in Central Asian countries decreases suppliers' competitiveness, especially to Russia's modern retail formats. While this paper points to regulation of the retail sector within Russia as well as at the level of the WTO, and also to rising competition within the Russian retail sector itself, as possible reasons for the alteration perceived by Central Asian suppliers, we do not really know if and to what extent the sourcing strategies of Russian buyers are also changing for other reasons, including chain governance. This underlines the point that more research needs to be done in Russia to provide insight into exactly how sourcing strategies are changing, and the extent to which this is merely due to regulation or, for example, also part of the broader rationalization of supermarkets' supply chain strategies, as has been observed in Western economies. Another factor at play during, and prior to, the time of fieldwork was the global financial crisis, which very possibly also influenced Russian buyers' governance, not least in terms of finance.

The Central Asia-Russia GVC in focus in this paper has a particular character due to the situation of suppliers as well as buyers in what has been termed in this paper a territory transition. It has been argued here that this brings about specific methodological and analytical challenges, in that change is ongoing to a relatively large extent at both ends of the chain. Change is an essential factor in such a context. While capturing a glimpse of suppliers' possibilities in Russia at the time of the fieldwork, in terms of supplier-buyer relations and at least perceived governance of Russian buyers, the study has therefore also attempted to capture how these factors change over time. This has been done by focusing on suppliers' perceptions of how the tasks they are expected to perform in GVCs governed by Russian buyers have altered. This approach obviously has implications in that a onesided story emerges based on perceptions rather than empirical facts. Nevertheless, Central Asian respondents across three countries do point to similar challenges and changes, while these were also triangulated with information provided by for example business organizations, supporting the validity of such results.

\section{ACKNOWLEDGEMENTS}

Empirical data used in this paper were originally collected for a GVC background study conducted 
for the World Bank in 2009. I am therefore deeply indebted to the World Bank team led by Souleymane Coulibaly (World Bank, Washington DC) and comprising Asset Nussupov (Kazakhstan Country Office consultant); Zarina Kosymova and Shuhrat Mirzoev (Tajikistan Country Office consultants); Shamsia Ibragimova (Kyrgyz Republic Country Office consultant) and myself (Washington Office consultant). Jakob Lindahl also contributed to data collection and provided valuable comments throughout the process. I am also thankful to all those central Asian business managers who provided valuable information, knowledge and opinions for the study. Though not directly funded by any organization, this paper did indirectly benefited from the financial support from the World Bank, and thus from the governments of Finland, Norway, Sweden, and the United Kingdom through a contribution from the Multi-Donor Trust Fund for Trade and Development.

\section{REFERENCES}

Belaya, V., and Hanf, J. H. (2010) Foreign direct investment as an agent of change in Russian agrifood business: consequences of the export of chain management concepts by foreign investors, Post-Communist Economies, 22(1): 55-72.

Coe, N. M., and Hess, M. (2005) The internationalization of retailing: implications for supply network restructuring in East Asia and Eastern Europe, Journal of Economic Geography, 5(4): $449-473$.

Coe, N. M., and Wrigley, N. (2007) Host economy impacts of transnational retail: The research agenda, Journal of Economic Geography, 7: 341-371.

Dawson, J. A. (2007) Scoping and conceptualising retailer internationalisation, Journal of Economic Geography, 7: 373-397.

Dicken, P., Kelly, P. F., Olds, K., and Wai-Chung Yeung, H. (2001) Chains and networks, territories and scales: towards a relational framework for analysing the global economy, Global Networks, 1: 89-112. 
Dolan, C. and Humphrey, J. (2000) Governance and Trade in Fresh Vegetables: The Impact of UK Supermarkets on the African Horticulture Industry, Journal of Development Studies, 37 (2): $147-176$.

Dolan, C. and Humphrey, J. (2004) Changing governance patterns in the trade in fresh vegetables between Africa and the United Kingdom, Environment and Planning A, 36(3) 491 - 509.

Dries, L., Reardon, T., and Swinnen, J. F. M. (2004) The rapid rise of supermarkets in Central and Eastern Europe: Implications for the agrifood sector and rural development, Development Policy Review, 22 (5): 525-556.

Gereffi, G. (1994) The organisation of buyer-driven global commodity chains: how US retailers reshape overseas production networks. In Gereffi, G and M. Korzeniewicz (eds.), Commodity Chains and Global Development, Westport: Praeger, pp. 95-122.

Gereffi, G. (1995) Global Production Systems and Third World Development. In Stallings, B. (ed) global change, regional response: the international context of development. University Press, Cambridge.

Gereffi, G., Humphrey, J., and Sturgeon, T. (2005) The governance of global value chains, Review of International Political Economy, 12 (1): 78-104.

Gibbon, P. and Ponte, S. (2005) Trading Down: Africa, Value Chains, and the Global Economy. Philadelphia: Temple University Press.

Gibbon, P. and Lazarro, E. (2010) Agro-food standards and Africa: An introduction. In (Eds) Gibbon, P., Ponte, S. and Lazaro, E., Global Agro-food trade and standards: Challenges for Africa, International Political Economy Series, Basingstoke: Palgrave Macmillan.

Gibbon, P., Ponte, S. and Bair, J. (2008) Governing global value chains: An introduction, Economy and Society, 37(3), 315-333.

Hess, M. (2004) 'Spatial' relationships? Towards a reconceptualization of embeddedness, Progress in Human Geography, 28(2): 165-186. 
Humphrey, J. and Schmitz, H. (2002) How does insertion in global value chains affect upgrading in industrial clusters?, Regional Studies, 36: 1017-1027.

Kalotay, K. (2008) Russian transnationals and international investment paradigms, Research in International Business and Finance, 22(2): 85-107.

Kaplinsky, R. (2000) Globalisation and unequalisation: What can be learned from value chain analysis?, The Journal of Development Studies, 37(2): 117-146.

Kolchevnikova, O. (2010) Russian trade law equals transparency? Russian federation, Global Agricultural Information Network, Report RSATO1002, USDA Foreign Agricultural service.

Kolchevnikova, O. (2011) Russian retail market continues expansion, Russian Federation, Retail Foods, Global Agricultural Information Network, Report RSATO01110, USDA Foreign Agricultural service.

Lorentz, H., Häkkinen, L. and Hilmola, O-P. (2006) Analysis of the Russian retail sector: Prospects for cross-border M\&A activity, Baltic Journal of Management 1(2): 148-168.

Nadvi, K. (2008) Global standards, global governance and the organization of global value chains, Journal of Economic Geography, 8(3): 323-343.

Neilson, J. and Pritchard, B. (2009) Value Chain Struggles: Institutions and Governance in the Plantation Districts of South India. RGS-IBG Book Series. Chichester: Wiley-Blackwell.

Pavlinek and Zenka (2011) Upgrading in the automotive industry in the automotive industry: firmlevel evidence from Central Europe, Journal of Economic Geography, 11 (3), 559-586.

PriceWaterHouseCoopers (2008) Shopping for the future. Russian Retail Market Survey. Retail and Consumer.

Reardon, T., Henson, S., and Berdegué, J. (2007) 'Proactive fast-tracking' diffusion of supermarkets in developing countries: Implications for market institutions and trade, Journal of Economic Geography, 7(4): 399-431. 
Reardon, T. and Hopkins, R. (2006) The supermarket revolution in developing countries: Policies to address emerging tensions among supermarkets, suppliers and traditional retailers, The European Journal of Development Research, 18(4): 522-545.

Roberts, H., G. (2005) Auchan's entry into Russia: prospects and research implications, International Journal of Retail \& Distribution Management, 33(1): 49-68.

Smith, A., Pickles, J., Bucek, M., Pastor, R. and Begg, R. (2014), The political economy of global production networks: Regional industrial change and industrial upgrading in the Eastern European clothing industry, Journal of Economic Geography 14(6) 1023-1071.

Swinnen, J. F. M., and Maertens, M. (2007) Globalization, privatization, and vertical coordination in food value chains in developing and transition countries, Agricultural Economics, 37, Issue supplement S1: 89-102.

Tacconelli, W., and Wrigley, N. (2009) Organizational challenges and strategic responses of retail TNCs in post-WTO-entry China, Economic Geography, 85(1): 49-73.

Wandel, J. (2008) Agroholding or Clusters in Kazakhstan's Agri-Food Sector? IAMO Forum, AgriFood Business: Global Challenges - Innovative Solutions, June 25 - 27, 2008.

World Bank (2005a) Doubling Tajik Horticultural Production until 2010: Reality or Utopia? A Sector Review, Washington, DC: World Bank.

World Bank (2005b) Fruit and Vegetable Study for Tajikistan and Uzbekistan, Memo paper, Washington, DC: World Bank.

World Bank (2007) Kyrgyz Republic livestock sector review: Embracing the new challenges, Open Knowledge Repository, Washington, DC: World Bank.

World Bank (2011) Central Asia: Expanding Trade by Connecting with Market, World Bank Report No. 53556-ECA. Poverty Reduction and Economic Management Unit, Europe and Central Asia Region, Washington DC: World Bank. 
Wrigley, N., Coe, N. M., and Currah, A. D. (2005) Globalizing retail: conceptualizing the distribution-based transnational corporation (TNC), Progress in Human Geography, 29(4): $437-457$.

Wrigley, N., and Lowe, M. (2007) Introduction: Transnational retail and the global economy, Journal of Economic Geography, 7(4): 337-340. 
Box 1: Overall interview themes
a. Firm characteristics
b. Tasks performed
c. Supply
d. Markets/export
e. Regulation
f. Transport and logistics
g. Upgrading
h. Requirements from buyers
i. Finance and local institutional support
j. Future prospects and challenges 